\title{
Territorialization, urban planning, sustainable development and smart cities for the development
}

\author{
EDITORIAL
}

Anderson Catapan

catapan@utfpr.edu.br

Universidade Tecnológica Fede

Antonio Gonçalves de Oliveira

Antonio Gonçalves
agoliveira@utfpr.edu.br

Universidade Tecnológica Federal do Paraná, Curitiba, Paraná, Brasil.
This editorial features articles from the second issue of the ninth volume of the Brazilian Journal of Planning and Development - Revista Brasileira de Planejamento e Desenvolvimento (RBPD). This issue has contributed to the planning and development, as in previous and usual numbers of this journal, by teachers from Brazil.

This issue brought discussions about the topics territorialization, urban planning, sustainable development, extrajudicial collection, sustainability, smart cities, among others.

We thank you for the contribution of all the authors and reviewers of our journal. Presented the articles of this issue, we wish a great and useful reading to all! 